\title{
Sistem Bank Data Wajib Pajak KPP Pratama Pekanbaru Senapelan
}

\author{
Bima Saptayona Winken Somopawiro dan Raymond Maulany \\ Fakultas Teknologi Informasi, Universitas Advent Indonesia
}

\begin{abstract}
Abstrak
Kantor Pelayanan Pajak (KPP) Pratama Pekanbaru Senapelan melaksanakan pelayanan di bidang perpajakan kepada masyarakat dalam lingkup wilayah kerja KPP Pratama Senapelan. Saat ini data Wajib Pajak KPP Pratama Pekanbaru Senapelan sudah tersimpan dalam bentuk data digital. Sesuai dengan surat perintah Kementerian Keuangan Republik Indonesia Nomor : S - 333/WPJ.02/2016, maka secara ringkas disampaikan bahwa setiap KPP Provinsi Riau harus menyediakan dan membuat sebuah media sebagai Pusat Penyimpanan dan Pembagian Data Wajib Pajak. Karena banyaknya kebutuhan tersebut, lajur informasi dan data haruslah efisien dan efektif dalam pendistribusiannya. Adapun tujuan dari penelitian ini adalah (1)Untuk membangun Sistem Bank Data Wajib Pajak KPP Pratama Pekanbaru Senapelan. (2)Untuk merancang Sistem Bank Data Wajib Pajak KPP Pratama Pekanbaru Senapelan dan (3)Untuk mengimplementasikan Sistem Bank Data Wajib Pajak KPP Pratama Pekanbaru Senapelan. Adapun kesimpulan dari penelitian ini adalah (1)Sistem Bank Data Wajib Pajak pada KPP Pratama Pekanbaru Senapelan membantu KPP Pratama Pekanbaru Senapelan dalam hal menyimpan data Wajib Pajak ke dalam database sehingga data tidak mudah hilang atau rusak dan membagikan data yang telah disimpan tersebut, (2)Sistem Bank Data Wajib Pajak pada KPP Pratama Pekanbaru Senapelan memiliki tampilan yang baik sehingga para pengguna dapat menggunakan sistem ini dengan mudah karena memiliki tampilan yang user-friendly, (3)Sistem Bank Data Wajib Pajak pada KPP Pratama Pekanbaru Senapelan memiliki hak akses untuk masuk ke dalam sistem sehingga setiap pengguna telah memiliki Leve/mereka masing-masing yang nantinya berguna untuk menyimpan data sesuai dengan hak akses user atau user lain yang dituju.
\end{abstract}

Kata-kata Kunci : Bank Data, Penyimpanan Data, Pembagian Data, Sistem, DFD

\section{Taxpayer Data Bank System at KPP Pratama Senapelan Pekanbaru}

\begin{abstract}
Kantor Pelayanan Pajak (KPP) Pratama Pekanbaru Senapelan carry out services in the field of taxation to the public within the scope of the KPP Pratapelan working area. At present the Pekanbaru Senapelan KPP Taxpayer data has been stored in the form of digital data. In accordance with the letter of instruction of the Ministry of Finance of the Republic of Indonesia Number: S - 333 / WPJ.02 / 2016, it is briefly stated that each Riau Province KPP must provide and make a media as a Taxpayer Data Storage and Distribution Center. Because of these many needs, the information and data lanes must be efficient and effective in their distribution. The objectives of this research are (1) To build a Pekanbaru Taxpayer Taxpayer Data Bank System. (2) To design the KPP Pekanbaru Senapelan Taxpayer Data Bank System and (3) To implement the KPP Pekanbaru Senapelan Taxpayer Data Bank System. The conclusions of this study are (1) Taxpayer Data Bank System in the KPP Pekanbaru Senapelan to assist the KPP Pekanbaru Senapelan in terms of storing Taxpayer data into a database so that the data is not easily lost or damaged and share the data that has been stored, (2) The Taxpayer Data Bank System at KPP Pekanbaru Senapelan has a good appearance so that users can use this system easily because it has a user-friendly display, (3) The Taxpayer Data Bank System on the KPP Pekanbaru Senapelan primarily has access rights to enter into the system so that each user has their own level which will be useful for storing data in accordance with the permissions of the user or other intended user.
\end{abstract}

Keywords: Data Bank, Data Storage, Data Sharing, System, DFD 


\section{Pendahuluan}

Kantor Pelayanan Pajak (KPP) Pratama Pekanbaru Senapelan adalah salah satu unit kerja Direktorat Jenderal Pajak (DJP) yang melaksanakan pelayanan di bidang perpajakan kepada masyarakat baik yang telah terdaftar sebagai Wajib Pajak (WP) maupun yang belum terdaftar sebagai Wajib Pajak di dalam lingkup wilayah kerja KPP Pratama Senapelan. KPP Pratama Pekanbaru Senapelan setiap hari melayani ratusan WP dengan berbagai kebutuhan baik itu pertanyaan, keluhan, instalasi aplikasi pajak, pendaftaran e-billing dan e-filing, dan masih banyak hal lainnya.

Saat ini pengolahan data Wajib Pajak KPP Pratama Pekanbaru Senapelan sudah menggunakan sistem komputerisasi dalam hal pengurusan Surat Pemberitahuan Tahunan (SPT), e-registration, efaktur, e-billing, e-filing, dan masih banyak sistem komputerisasi lainnya yang bertujuan untuk mempermudah Wajib Pajak dan Fiskus melakukan pengurusan pajak dan penggalian potensi pajak, sehingga data WP yang tersimpan sudah berbentuk data digital. Dengan sistem komputerisasi tersebut, tentu akan banyak data digital yang tersimpan dengan kapasitas yang bervariasi tentunya. Akan tetapi, belum ada sistem yang secara khusus dibuat atau digunakan untuk menangani sistem pembagian data dan penyimpanan data Wajib Pajak.

Sesuai dengan surat perintah Kementerian Keuangan Republik Indonesia Nomor : S 333/WPJ.02/2016 yang ditujukan untuk Kepala Kantor Pelayanan Pajak Wilayah DJP Riau dan Kepulauan Riau dalam rangka optimalisasi pemanfaatan data untuk penggalian potensi pajak tahun 2016, maka secara ringkas disampaikan bahwa setiap KPP harus menyediakan dan membuat sebuah media sebagai Pusat Penyimpanan dan Pembagian Data Wajib Pajak yang ada pada KPP tersebut dan dapat diakses dengan mudah oleh seluruh pegawai yang terkait dengan pemanfaatan data tersebut serta monitoring data yang telah ditindaklanjuti.

Karena banyaknya kebutuhan tersebut, lajur informasi dan data haruslah efisien dan efektif dalam pendistribusiannya. Data yang sangat banyak harus dapat dikendalikan dengan baik sehingga data dapat sampai dengan cepat dan tepat pada tujuan. Sistem yang belum dapat membantu sepenuhnya dalam hal pusat penyimpanan data dan pembagian data menjadi salah satu faktor yang menjadi hambatan KPP Pratama Pekanbaru Senapelan.

\section{Landasan Teori}

Menurut Indrajit dalam Hutahaean (2015:1), mengemukakan bahwa sistem mengandung arti kumpulan-kumpulan dari komponen-komponen yang dimiliki unsur keterkaitan antara satu dengan lainnya.

Menurut Azhar Susanto dalam Djahir dan Pratita (2015:6), "Sistem adalah kumpulan/grup dari sub sistem/bagian/komponen apa pun, baik fisik ataupun non fisik yang saling berhubungan satu sama lain dan bekerja sama secara harmonis untuk mencapai satu tujuan tertentu".

Berdasarkan definisi yang telah dikemukakan oleh para ahli di atas, dapat disimpulkan bahwa sistem merupakan kumpulan elemen-elemen yang saling berkaitan dan berinteraksi untuk mencapai suatu tujuan tertentu dengan cara menekankan pada prosedur yang ada atau menekankan pada elemennya.

Menurut Linda Marlinda dalam Sarwindah (2016:78), sistem basis data adalah suatu sistem menyusun dan mengelola record-record menggunakan komputer untuk menyimpan atau merekam serta memelihara data operasional lengkap sebuah organisasi atau perusahaan sehingga mampu menyediakan informasi yang optimal yang diperlukan pemakai untuk proses pengambilan keputusan. Menurut Binarso, Sarwoko, dan Bahtiar (2012:75), client - server merupakan sebuah paradigma dalam teknologi informasi yang merujuk kepada cara untuk mendistribusikan aplikasi ke dalam dua pihak yaitu pihak client dan pihak server.

Adapun metode pemodelan yang berperan dalam proses perancangan Sistem Bank Data Wajib Pajak KPP Pratama Pekanbaru Senapelan antara lain:

1. ERD (Entity Relationship Diagram), menurut Widodo, Aris, Djajal, dan Beta dalam Binarso, Sarwoko, dan Bahtiar (2012:74), model data ERD merupakan diagram yang menggambarkan keterhubungan antar objek-objek data. Model data ERD terbagi menjadi entitas, atribut, relasi dan kardinalitas.

2. DFD (Data Flow Diagram), menurut Roger dalam Binarso, Sarwoko, dan Bahtiar (2012:74), DFD adalah sebuah teknik grafis yang menggambarkan aliran informasi dan transformasi yang diaplikasikan saat data bergerak dari input menjadi output. Komponen DFD dibagi menjadi proses, alur data, data store dan external entity.

Adapun bahasa pemrograman yang digunakan dalam pembuatan Sistem Bank Data Wajib Pajak KPP Pratama Pekanbaru Senapelan adalah sebagai berikut: 
1. HTML (Hyper Text Markup Language), menurut Binarso, Sarwoko, dan Bahtiar (2012:76), digunakan untuk mark up (penanda) terhadap suatu dokumen teks. Simbol mark up yang digunakan oleh HTML ditandai dengan tanda lebih kecil $(<)$ dan tanda lebihi besar $(>)$. Kedua tanda ini disebut tag. Tag yang digunakan sebagai penutup diberi karakter garis miring $(</>)$.

2. PHP (Hypertext Preprocessor), menurut Widodo, Aris, dkk. dalam Binarso, Sarwoko, dan Bahtiar (2012:76), merupakan bahasa scripting yang tergabung menjadi satu dengan HTML dan dijalankan pada server side atau semua perintah yang diberikan akan secara penuh dijalankan pada server, sedangkan yang dikirimkan ke klien (browser) hanya berupa hasilnya saja.

3. CSS(Cascading Style Sheet), menurut Binarso, Sarwoko, dan Bahtiar (2012:76), merupakan sebuah dokumen yang berguna untuk melakukan pengaturan pada komponen halaman web, inti dari dokumen ini adalah memformat halaman web standar menjadi bentuk web yang memiliki kualitas yang lebih indah dan menarik.

4. Javascript, menurut Widodo, Aris, dkk. dalam Binarso, Sarwoko, dan Bahtiar (2012:76), adalah bahasa yang berbentuk kumpulan skrip yang fungsinya digunakan untuk menambahkan interaksi antara halaman web dengan pengunjung halaman web. Javascript dijalankan pada sisi klien yang akan memberikan kemampuan fitur-fitur tambahan halaman web yang lebih baik dibandingkan fitur-fitur yang terdapat pada HTML.

5. XAMPP, menurut Dudul dalam Binarso, Sarwoko, dan Bahtiar (2012:76), adalah sebuah software web server Apache yang di dalamnya sudah tersedia database server MySQL dan mendukung PHP programming.

\section{Perancangan Sistem \\ Analisa Kebutuhan}

Analisa kebutuhan sistem antara lain kebutuhan fungsional, perangkat lunak (software) dan perangkat keras (hardware).

\section{Kebutuhan fungsional}

Adapun analisa fungsi sistem setelah dilakukannya observasi langsung dan wawancara dengan pihak terkait adalah sebagai berikut:

1. Membuat fungsi Login menggunakan username dan password pada sistem.

2. Membuat fungsi tree menu yang responsive dengan dua folder utama yaitu Data Potensi dan Data Lain-lain.

3. Membuat fungsi unggah yang dapat membatasi kepada siapa data tersebut ditujukan.

4. Membuat fungsi unduh yang dapat membatasi akses terhadap data tersebut berdasarkan Level.

5. Membuat fungsi broadcast, yang dapat memberikan informasi secara umum pada bagian halaman depan sistem.

6. Membuat fungsi input, edit, delete terhadap pengguna yang ada pada sistem.

7. Membuat fungsi edit, delete terhadap pengguna yang ada pada sistem.

8. Membuat fungsi data konfirmasi yang merupakan data yang diunggah oleh Leve/ seksi dan Level User Kantor. Data yang diunggah tersebut akan menunggu konfirmasi dari Level Administrator.

9. Membuat fungsi data konfirmasi yang merupakan data yang diunggah oleh Leve/ seksi dan Level User Kantor. Data yang diunggah tersebut akan menunggu konfirmasi dari Level Administrator.

\section{Kebutuhan Perangkat Lunak (Software)}

Dalam pembangunan sistem ini, maka diperlukan beberapa perangkat lunak yang memenuhi kebutuhan pembuatan sistem antara lain:

1. Aplikasi XAMPP v3.2.2 sebagai web server.

2. Aplikasi Sublime Text 2 Version 2.0.2 Build 2221 sebagai text editor.

3. Google Chrome Version 57.0.2987.133 sebagai browser.

4. Windows 7 Ultimate sebagai operating system.

\section{Kebutuhan Perangkat Keras (Hardware)}

Perangkat keras yang dibutuhkan saat membangun dan untuk menjalankan sistem ini antara 
lain:
1. Processor
: Intel@ Core ${ }^{\mathrm{TM}}$ i3-3210 Processor @3.20 GHz (2CPUs)
2. Memory
: 4GB DDR3 RAM
3. Hard disk
: 1TB SATA

\section{Hasil Penelitian \\ Halaman Login}

Untuk dapat mengakses Sistem Bank Data KPP Pratama Pekanbaru Senapelan, User dapat memasukkan username dan password terlebih dahulu pada halaman login yang tersedia. User akan diarahkan ke halaman seperti gambar 1 . Pada halaman login ini, selanjutnya pengguna dapat menekan tombol GO untuk dapat masuk ke dalam Sistem Bank Data Wajib Pajak Pada KPP Pratama Pekanbaru Senapelan. Apabila pengguna memasukkan username dan password yang salah, maka pengguna tidak akan masuk ke dalam halaman awal sistem, dan harus memasukkan ulang username dan password pengguna.

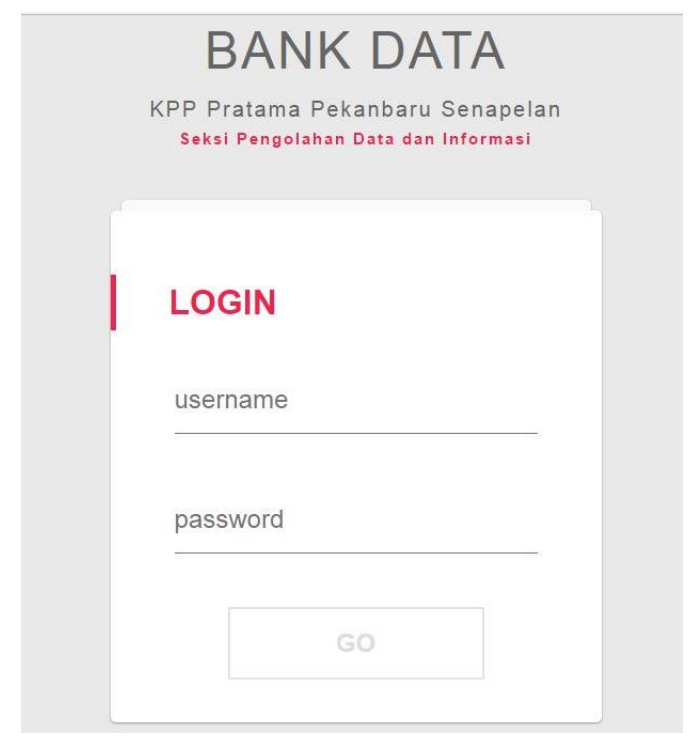

Gambar 1 Halaman Login

\section{Halaman Home seksi-seksi dan user kantor}

Halaman home ini akan menampilkan informasi umum tentang KPP Pratama Pekanbaru Senapelan seperti nama kantor, alamat, nomor telepon, fax, dan situs resmi dari Direktorat Jenderal Pajak. Pada halaman home, para pengguna akan melihat pengumuman pada bagian bawah layar, yang merupakan pengumuman seputar kegiatan yang akan diadakan di KPP Pratama Pekanbaru Senapelan. Pada bagian sebelah kiri home, akan terlihat menu yang dapat dipilih oleh para pengguna. Menu tersebut membagi data menjadi dua yaitu, data potensial dan data lain-lain yang di dalamnya terdapat sub-menu berisikan data yang telah diunggah oleh admin, user kantor ataupun seksi-seksi sesuai dengan level yang telah dipilih. Apabila pengguna ingin melakukan logout, pengguna dapat mengarahkan kursor pada nama user login yang berada pada bagian kanan atas dan menekan tombol logout yang akan muncul secara otomatis. Dapat dilihat seperti gambar 2. 


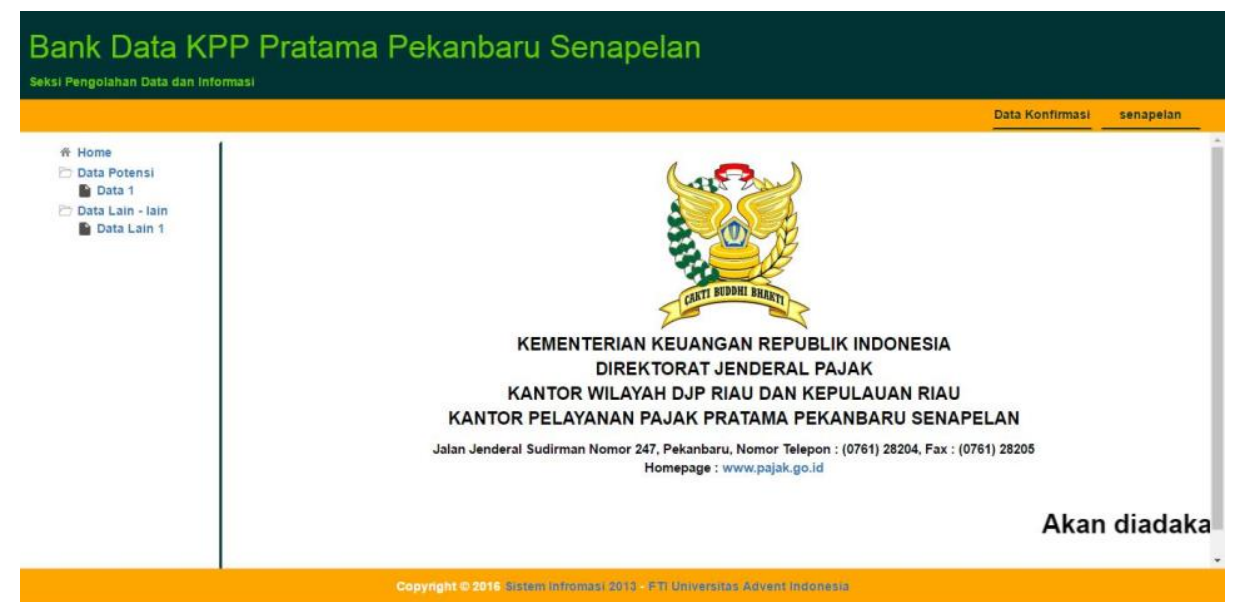

Gambar 2 Halaman Home seksi-seksi dan user kantor

\section{Halaman Unduh Admin}

Halaman Unduh Admin seperti gambar 3, memungkinkan Admin dapat mengunduh data yang telah diunggah oleh admin, seksi-seksi ataupun user kantor yang telah mengunggah data ke dalam sistem dengan cara menekan Nama File yang diinginkan. Admin juga dapat mengunggah, edit dan menghapus data dalam sistem. Pengguna juga dapat melakukan pengurutan data yang ada pada tabel dengan cara menekan judul yang ada pada setiap kolom.

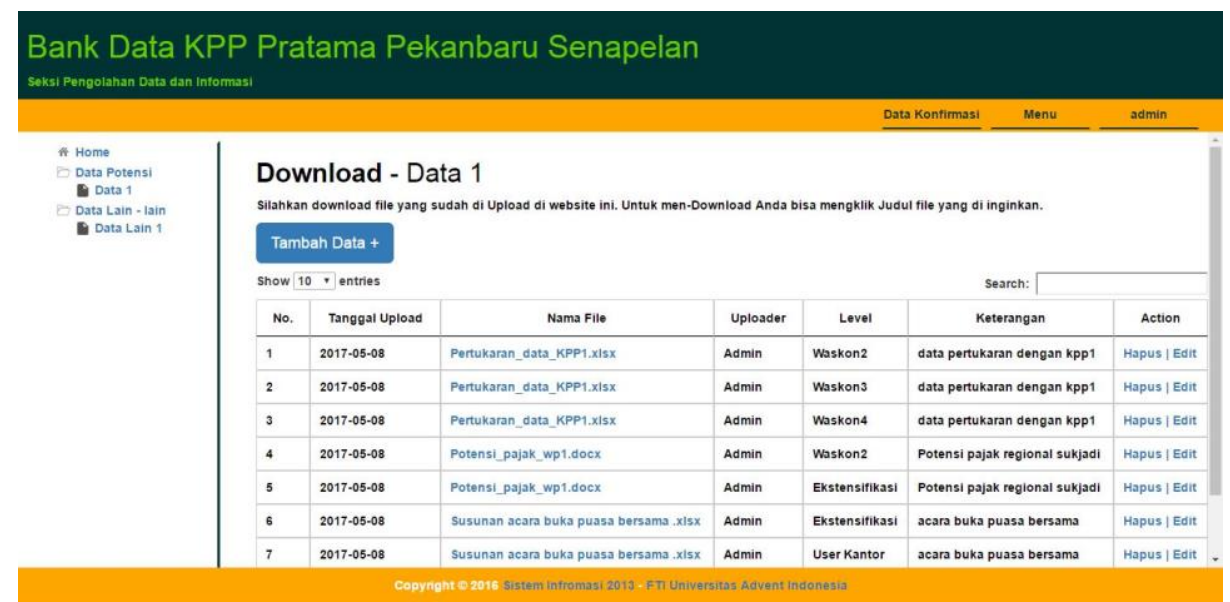

Gambar 3 Halaman Unduh Admin

\section{Halaman Data Konfirmasi Admin}

Pada saat seksi-seksi dan user kantor melakukan unggah data menggunakan akun mereka, otomatis admin akan mendapatkan notifikasi email untuk mengonfirmasi data yang telah diunggah oleh seksi-seksi ataupun user kantor dan data tersebut akan langsung masuk ke dalam halaman Data Konfirmasi Admin seperti gambar 4. Pada halaman ini, Admin harus melakukan konfirmasi terhadap data-data yang diunggah oleh seksi-seksi ataupun user kantor dengan cara menekan tombol konfirmasi yang ada pada setiap data yang diunggah. Admin juga dapat menghapus data yang diunggah oleh seksi-seksi ataupun user kantor apabila data tersebut tidak relevan dengan kebutuhan. Setelah data tersebut dikonfirmasi oleh Admin, otomatis data tersebut akan muncul pada halaman unduh level yang ditentukan. 


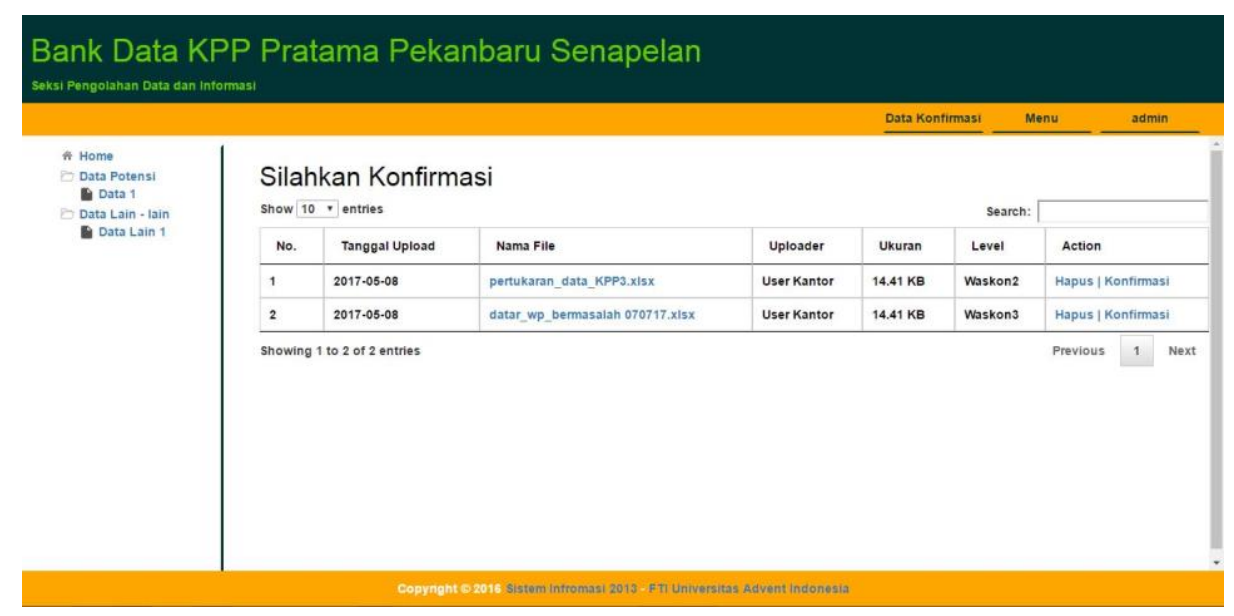

Gambar 4 Halaman Data Konfirmasi Admin

\section{Halaman Menu Broadcast}

Menu ini berfungsi untuk membuat pengumuman berjalan yang berada pada bawah halaman. Pengumuman ini berisikan tentang kegiatan yang ada di kantor, dan pengumuman lainnya. Admin dapat memilih Menu pada bagian kanan atas lalu memilih Broadcast seperti gambar 5 . Setelah itu Admin dapat mengisi kolom yang ada dengan pengumuman yang diinginkan seperti gambar 6 .

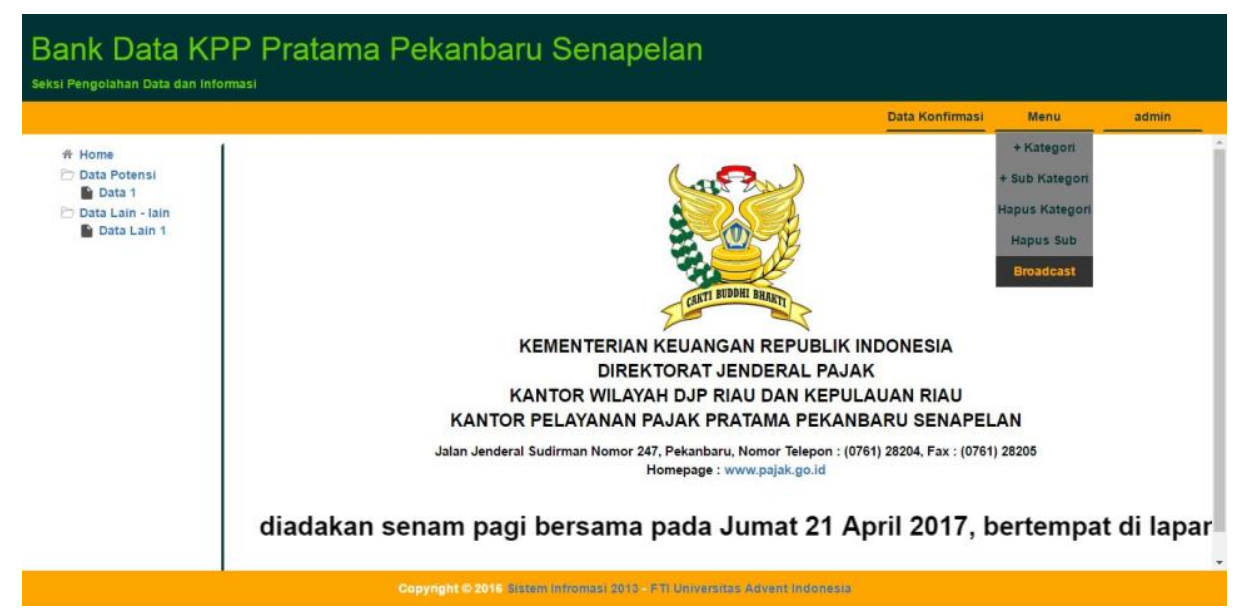

Gambar 5 Menu pilih broadcast

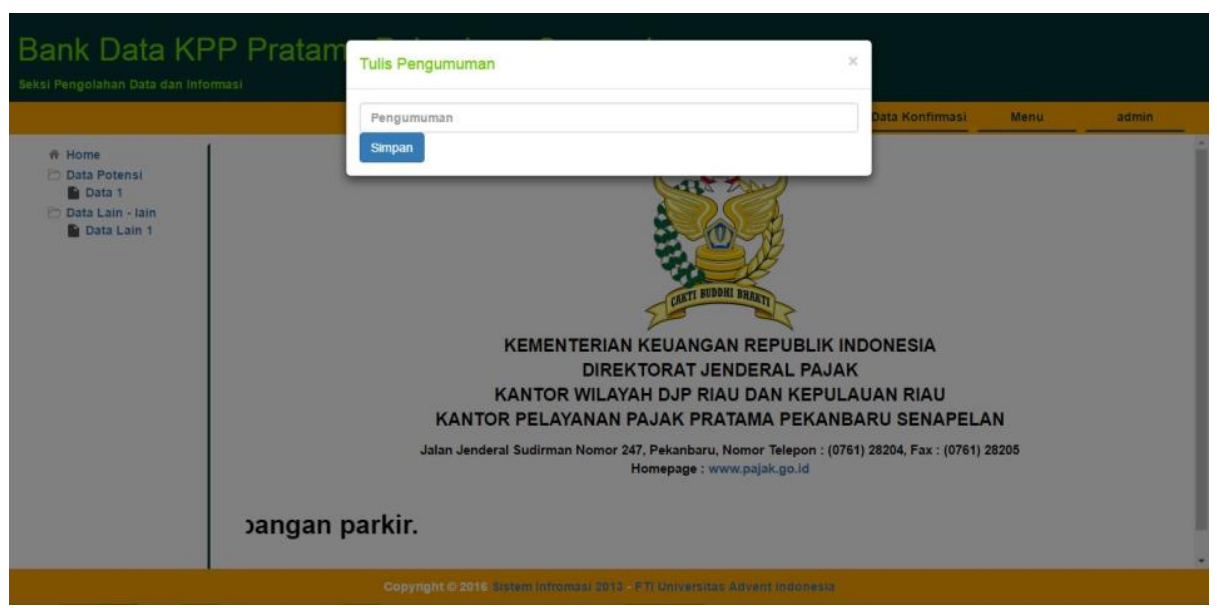

Gambar 6 Menu isi pengumuman 
Halaman Menu Data User

Menu ini memungkinkan Admin agar dapat melihat semua user yang terdaftar. Untuk melihat user yang terdaftar, memilih Menu Admin yang tersedia pada bagian kanan atas halaman dan selanjutnya menekan tombol Data User seperti gambar 7. Setelah itu apabila Admin ingin menghapus user yang terdaftar, Admin dapat menekan tombol hapus yang ada pada setiap data user seperti gambar 8. Untuk mengedit data user yang terdaftar, Admin dapat menekan tombol Edit yang tersedia pada setiap data user, selanjutnya Admin akan masuk ke halaman Edit seperti gambar 9.

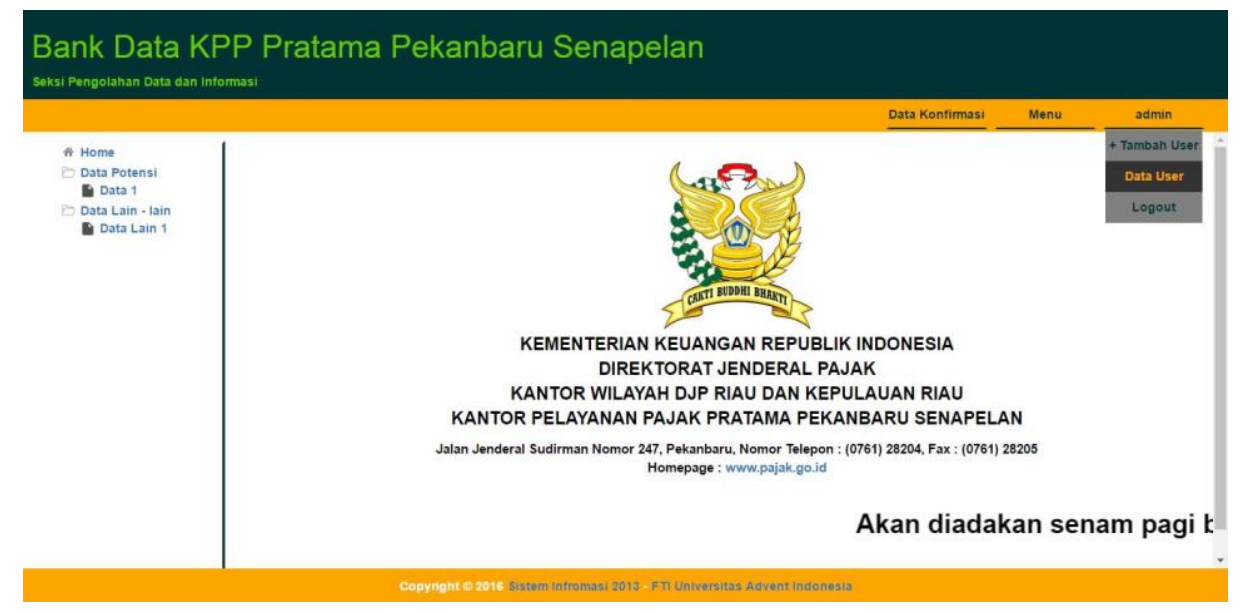

Gambar 7 Menu Data User

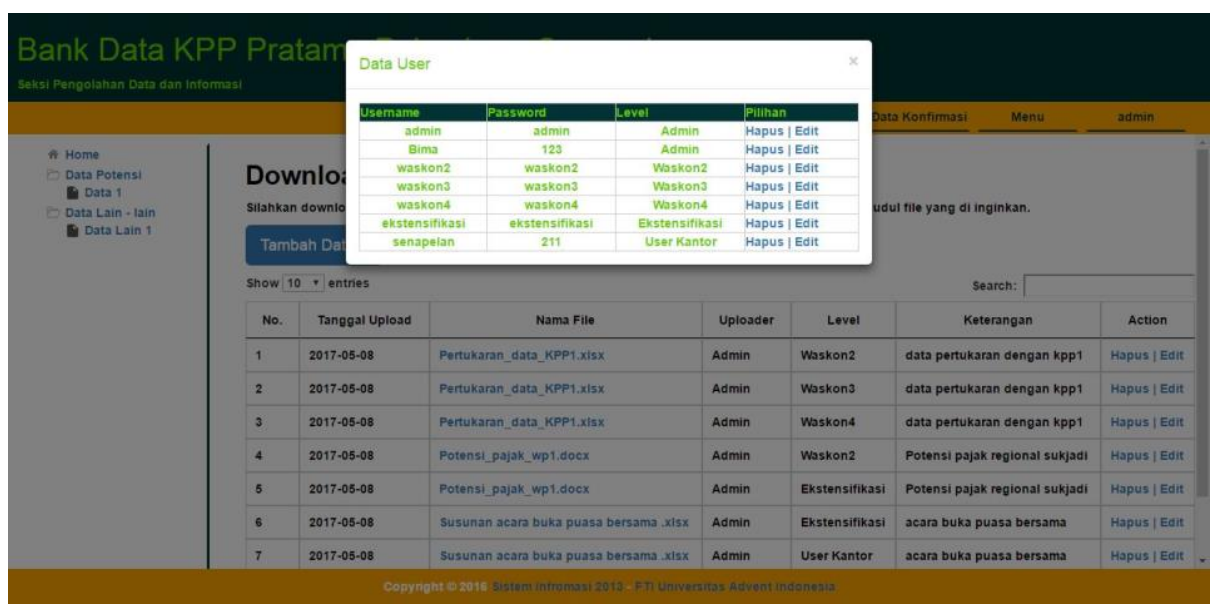

Gambar 8 Menu Pilih Data User 


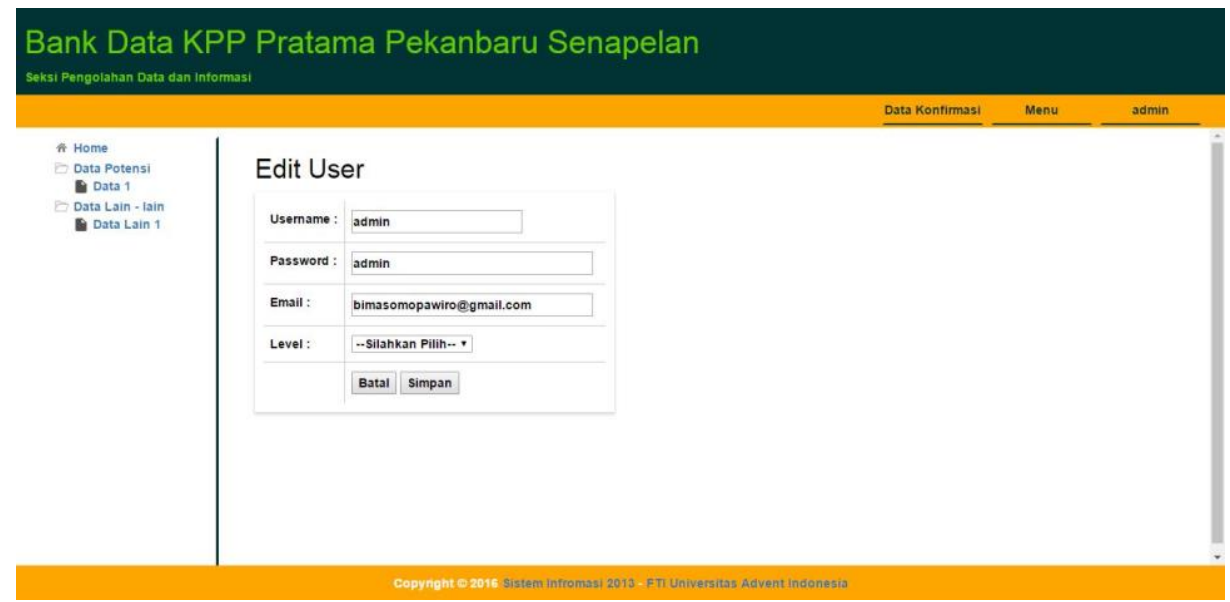

Gambar 9 Menu Edit Data User

Halaman Fungsi Pencarian Data

Fungsi Search ini dapat digunakan oleh Admin dengan mengetikkan kata kunci nama file yang dicari pada bagian kolom kanan atas seperti gambar 10. Setelah mengetikkan kata kunci, hasil dari pencarian tersebut akan muncul pada halaman sesuai dengan kata kunci dari nama file yang dicari. Kata kunci tersebut dapat diambil dari semua kolom yang ada.

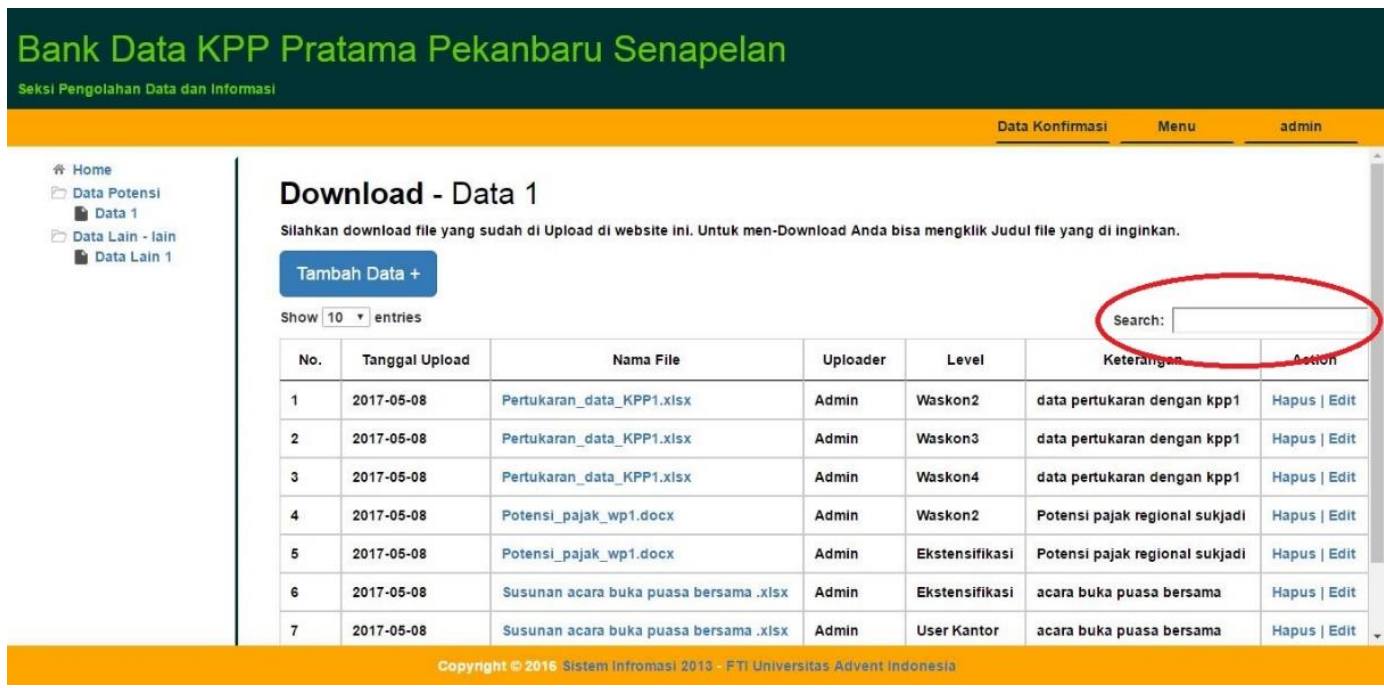

Gambar 10 Fungsi Pencarian Data

\section{Kesimpulan dan Saran \\ Kesimpulan}

Setelah penulis melakukan perancangan terhadap sistem yang telah dikerjakan, maka penulis mengambil kesimpulan sebagai berikut:

1. Sistem Bank Data Wajib Pajak pada KPP Pratama Pekanbaru Senapelan membantu KPP Pratama Pekanbaru Senapelan dalam hal menyimpan data Wajib Pajak ke dalam database sehingga data tidak mudah hilang atau rusak dan membagikan data yang telah disimpan tersebut.

2. Sistem Bank Data Wajib Pajak pada KPP Pratama Pekanbaru Senapelan memiliki hak akses untuk masuk ke dalam sistem sehingga setiap pengguna telah memiliki Leve/ mereka masingmasing yang nantinya berguna untuk menyimpan data sesuai dengan hak akses useratau user lain yang dituju. 


\section{Saran}

Penulis memberikan beberapa saran untuk pengembangan penelitian ini, adapun saran-saran sebagai berikut:

1. Sistem Bank Data Pada KPP Pratama Pekanbaru Senapelan sebaiknya dapat menampilkan isi dari data yang diunggah secara langsung tanpa harus mengunduh data tersebut terlebih dahulu.

\section{Referensi}

1. Ahmar, Ansari Saleh. (2013). Modifikasi CMS Template Lokomedia. Yogyakarta: Garudhawacha. Beal, Vangie. (2016). Webopedia. [Online]. Tersedia: http://www.webopedia.com/TERM/R/repository.html. [21 November 2016].

2. Binarso, Yusi Ardi; Sarwoko, Eko Adi dan Bahtiar, Nurdin. (2012). Pembangunan Sistem Informasi Alumni Berbasis Web Pada Program Studi Teknik Informatika Universitas Diponegoro. Journal of Informatics and Technology, 1(1), $72-84$.

3. Cambridge University Press. (2016). Cambridge Dictionary. [Online]. Tersedia: http://dictionary.cambridge.org/dictionary/english/repository. [21 November 2016].

4. Direktorat Jenderal Pajak Republik Indonesia. (2012). Direktorat Jenderal Pajak Kementerian Keuangan. [Online]. Tersedia: http://www.pajak.go.id/content/belajar-pajak [13 November 2016].

5. Djahir, Yulia dan Pratita, Dewi. (2015). Bahan Ajar Sistem Informasi Manajemen. Edisi 1. Yogyakarta: Deepublish.

6. Hutahaean, Jeperson. (2015). Konsep Sistem Informasi. Edisi 1. Yogyakarta: Deepublish.

7. Oxford University Press. (2016). English Oxford Living Dictionaries. [Online]. Tersedia: https://en.oxforddictionaries.com/definition/us/repository/ [21 November 2016].

8. Sarwindah. (2016). Sistem Informasi Manajemen Pemesanan Buku Pada Toko Buku Nuris. TEKNOSI, 2(2), Agustus 2016.

9. Supono dan Putratama, Virdiandry. (2016). Pemrograman Web dengan Menggunakan PHP dan Framework Codeigniter. Yogyakarta: Deepublish. 